\title{
Analysis of Factors Affecting Islamic Bank Financing for the Fisheries Sector in Indonesia
}

\author{
Nur Laili ${ }^{1^{*}}$, Hendri Tanjung ${ }^{1}$ \\ ${ }^{1}$ Mahasiswa Ekonomi Syariah Pascasarjana UIKA Bogor \\ 2 Dosen Ekonomi Syariah Pascasarjana UIKA Bogor \\ *Email: nurlaili1136@gmail.com
}

\begin{abstract}
The development of the fisheries sector in Indonesia should get more attention, especially in efforts to increase fishing businesses, limited financial access is still a problem that must be faced by the fisheries sector. Thus, Islamic banking can play a significant role in providing financing for the development of national fisheries. This study analyzes the factors that influence fisheries financing in Islamic banking in Indonesia and how efforts to increase fisheries sector financing. The processed data source is the monthly statistics of the Islamic banking industry from October 2014 to May 2019, and the method of analysis of this study uses VAR / VECM. The results showed that the NPF and PUAS affect fishery financing in the short term negatively and significantly. Whereas in the long term INF, NPF, PUAS, and ISBIS negatively affect fishery financing, as for CAR, and FDR affects fishery financing positively. Furthermore, SBK, and MRP do not affect fishery financing, both short-term and long-term. This study recommends an increase in the proportion of fishery financing along with an increase in Islamic banking capital, increased monitoring of fishery financing, and strengthening of national monetary policy instruments.
\end{abstract}

Keyword: fisheries financing, Islamic banking, VAR / VECM

\begin{abstract}
Abstrak
Berkembangnya sektor perikanan di Indonesia hendaknya dapat perhatian lebih, terutama dalam upaya peningkatan usaha-usaha perikanan, keterbatasan akses finansial masih menjadi problem yang harus dihadapi sektor perikanan. Dengan demikian, perbankan syariah dapat memainkan peran yang signifikan dalam menyediakan pembiayaan bagi pengembangan perikanan nasional. Penelitian ini menganalisis faktor-faktor yang mempengaruhi pembiayaan perikanan pada perbankan syariah di Indonesia dan bagaimana upaya peningkatan pembiayaan sektor perikanan. Adapun sumber data yang diolah adalah statistik bulanan industri perbankan syariah dari bulan Oktober 2014 hingga Mei 2019 , dan metode analisis penelitian ini menggunakan VAR/VECM. Hasil penelitian menunjukkan bahwa Non Performing Financing (NPF) dan Pasar Uang Antarbank Berdasarkan Prinsip Syariah (PUAS) mempengaruhi pembiayaan perikanan pada jangka pendek secara negatif dan signifikan. Sedangkan Pada jangka panjang Inflasi (INF), NPF, PUAS dan Imbalan Sertifikat Bank Indonesia Syariah (ISBIS) mempengaruhi pembiayaan perikanan secara negatif, adapun Capital Adequacy Ratio (CAR), dan Financial to Deposit Ratio (FDR) mempengaruhi pembiayaan perikanan secara positif. Selanjutnya Suku Bunga Kredit (SBK), dan Margin Rata- rata Pembiayaan (MRP) tidak mempengaruhi pembiayaan perikanan, baik jangka pendek maupun jangka panjang. Penelitian ini merekomendasikan peningkatan proporsi pembiayaan perikanan seiring dengan peningkatan modal perbankan syariah, peningkatan monitoring pembiayaan perikanan, dan penguatan instrumen kebijakan moneter nasional.
\end{abstract}

Kata kunci : pembiayaan perikanan, perbankan syariah, VAR/VECM

\section{PENDAHULUAN}

Sebagai negara kepulauan, Indonesia memiliki banyak potensi sumber daya alam, salah satunya ada pada sektor kelautan dan perikanan. Dengan garis pantai terpanjang di dunia $81.000 \mathrm{~km}$ dan gugusan pulau-pulau sebanyak 17.508, Indonesia memiliki potensi ikan yang ditaksir sebanyak 6.26 juta ton, potensi sebesar ini seharusnya dapat digunakan sebaik mungkin untuk mensejahterakan masyarakat. 
Apabila dilihat dari nilai Produk Domestik Bruto (PDB) perikanan berdasarkan harga konstan, maka dapat diketahui adanya peningkatan nilai dari tahun 2014 sampai dengan tahun 2016.

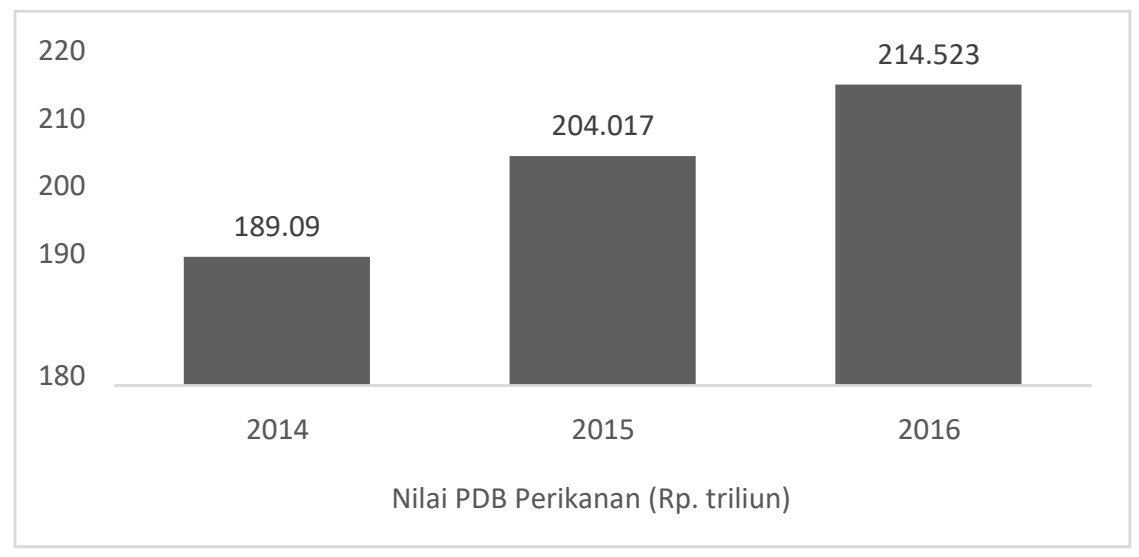

Gambar 1. Nilai PDB Perikanan, 2014-2016 (Rp. Triliun)

Sumber : Laporan Kinerja KKP 2016

Adapun angka pertumbuhan PDB Perikanan apabila dibandingkan dengan PDB kelompok pertanian dan PDB nasional, maka dapat diketahui bahwa pertumbuhan PDB perikanan berada di atas rata-rata pertumbuhan PDB nasional yang besarnya 5,02 persen dan pertumbuhan PDB pertanian yang besarnya hanya 3,25 persen.

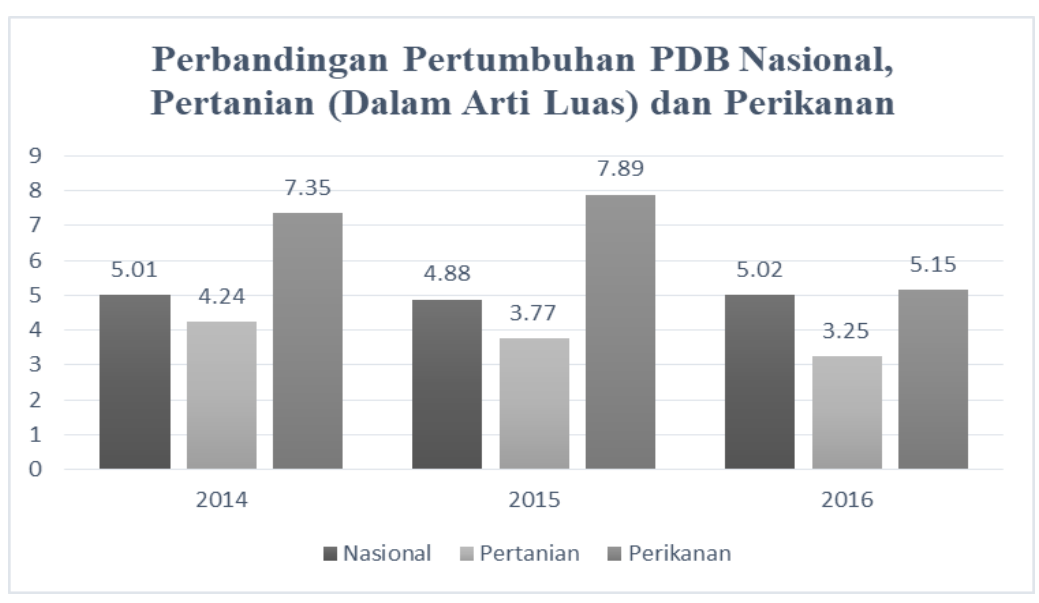

Gambar 2 : Perbandingan Pertumbuhan PDB Nasional, Pertanian (Dalam Arti Luas) dan Perikanan Sumber : Laporan Kinerja KKP 2016

Pada tahun 2017 tercatat angka sebesar Rp227,3 triliun PDB sektor perikanan (atas dasar harga konstan) dengan pertumbuhan sebesar 5,95 persen angka tersebut mengalami peningkatan dimana pada tahun 2016 pertumbuhannya adalah sebesar 5,15 persen.

Sebagai salah satu sektor yang memiliki peranan dalam perekonomian nasional, peranan sektor perikanan belum bisa dimanfaatkan seoptimal mungkin untuk mensejahterakan masyarakat khususnya para nelayan, sebagian dari mereka hidup dalam garis kemiskinan dengan tingkat kesejahteraan yang tergolong rendah, tercatat 25,14 persen dari seluruh penduduk miskin nasional adalah para nelayan. Kondisi yang demikian itu membuat para nelayan masih menghadapi kendala minimnya akses pembiyaaan, status masyarkat miskin seringkali dilekatkan pada nelayan, khususnya nelayan tradisional selain itu nelayan juga digambarkan sebagai kelompok masyarakat 
lemah, bodoh, tidak efesien dan tidak mampu merencanakan masa depannya (Velentina, 2018). Sektor kelautan dan perikanan merupakan salah satu sektor ekonomi yang memiliki peranan dalam pembangunan ekonomi nasional, khususnya dalam penyediaan bahan pangan protein, perolehan devisa, dan penyediaan lapangan kerja. Pada saat krisis ekonomi, perairan sektor perikanan semakin signifikan, terutama dalam hal mendatangkan devisa. Akan tetapi ironisnya,sektor perikanan selama ini belum mendapat perhatian yang serius dari pemerintah dan kalangan pengusaha, padahal bila sektor perikanan di kelola secara serius akan memberikan kontribusi yang lebih besar serta dapat mengentaskan kemiskinan masyarakat Indonesia terutama masyarakat nelayan (Mulyadi, 2007).

Menurut Nostbakken dan Sorensen investasi (2011) pada sektor perikanan tidak menemui jalan buntu dimana perkembangan sektor perikanan tidak diimbangi dengan akses permodalan yang mencukupi. Oleh sebab itu, minat lembaga perbankan pada pembiayaan sektor perikanan yang masih minim sekali menjadi permasalahan yang harus diselesaikan, untuk mengatasi masalah tersebut maka dibutuhkan kebijakan-kebijakan yang dapat mendorong terjadinya peningkatan investasi pada sentra-sentra pertumbuhan ekonomi kelautan dan perikanan. Upaya mensejahterakan masyarakat dengan memanfaatkan kelautan dan perikanan adalah keharusan, selaras dengan Pasal 2 Undang-Undang No.31 Tahun 2004 tentang Perikanan sebagaimana diubah dengan UndangUndang No.45 Tahun 2009 (UU Perikanan), pengelolaan perikanan dilaksanakan dengan berdasarkan asas manfaat. Penjelasan Pasal 2 huruf a menjelaskan asas manfaat sebagai "asas yang menunjukkan bahwa pengelolaan perikanan harus mampu memberikan keuntungan dan manfaat yang sebesarbesarnya bagi peningkatan kemakmuran dan kesejahteraan rakyat.” Dengan menilik secara cermat Pasal 3 huruf a Undang-Undang No.31 Tahun 2004 tentang Perikanan, pengertian "kesejahteraan rakyat" ditujukan utamanya untuk meningkatkan taraf hidup nelayan tradisional.

Salah satu alternatif sumber pembiyaan yang dapat digunakan dalam upaya pengembangan sektor kelautan dan perikanan ialah skema pembiyaan bank syariah, bank syariah adalah lembaga keuangan yang usaha pokoknya memberikan pembiayaan dan jasa-jasa lainnya dalam lalu lintas pembayaran serta peredaran uang yang pengoperasiannya disesuaikan dengan prinsip syariat islam (Muhammad, 2018). Penyaluran pembiayaan pada bank syariah merupakan salah satu bisnis utama dan oleh karena itu menjadi sumber pendapatan (Ikatan Bankir Indonesia, 2014). karakteristik perbankan syariah yang berbasis pada sektor riil dapat menjadi solusi alternatife untuk penambahan investasi dan peningkatan penyaluran bantuan permodalan di masyarakat. Berdasarkan data OJK, pembiayaan syariah untuk perikanan secara nominal tidak mengalami peningkatan yang signifikan, diman tercatat Rp. 1,40 triliun pada tahun 2016, Rp. 1,46 triliun pada tahun 2017, dan Rp. 1,20 triliun pada tahun 2018 (Statistik Pembiayaan Syariah OJK, 2019).

Jika dibandingkan dengan total keseluruhan pembiayaan perbankan syariah, yang terdiri dari Bank Umum Syariah (BUS), Unit Usaha Syariah (UUS), dan Bank Pembiayaan Rakyat Syariah (BPRS), maka proporsi pembiayaan perikanan pada perbankan syariah hingga Desember 2018 hanya mencapai angka 0.37 persen, presentase ini lebih rendah dibandingkan dengan pembiayaan pertanian, perburuan dan kehutanan yang tercatat sebesar 3.60 persen. Dengan demikian penting untuk ditelaah dan dianalisis faktor-faktor apa saja yang mempengaruhi pembiayaan sektor perikanan pada perbankan syariah di Indonesia, serta merumuskan rekomendasi kebijakan yang dapat diambil dalam upaya peningkatan pembiayaan syariah untuk perikanan.

Penelitian ini difokuskan untuk menganalisis faktor-faktor yang mempengaruhi pembiayaan bank syariah untuk sektor perikanan di Indonesia. Adapun variabel-variabel yang digunakan pada penelitian ini adalah : Inflasi, yang merupakan indikator makroekonomi; Non Performing Financing (NPF), Suku Bunga Kredit (SBK), Capital Adequacy Ratio (CAR), Financing to Deposit Ratio (FDR), dan Margin Rata-rata Pembiayaan (MRP), yang merupakan indikator makro perbankan syariah; Pasar Uang Antarbank Syariah (PUAS) dan Imbalan Sertifikat Bank Indonesia Syariah (SBIS), yang merupakan instrumen kebijakan moneter. 


\section{METODE PELAKSANAAN}

\subsection{Jenis dan Sumber Data}

Data penelitian ini menggunakan data sekunder bulanan dari Oktober 2014 sampai dengan Mei 2019 yang bersangkutan dengan pembiayaan yang diberikan Bank Umum Syariah (BUS) dan Unit Usaha Syariah (UUS). Data bersumber dari publikasi Bank Indonesia, Statistik Perbankan Syariah Otoritas Jasa Keuangan (SPS-OJK), dan Statistik Sistem Keuangan Indonesia (SSKI) serta data dari Badan Pusat Statistika Indonesia (BPS). Penelitian ini juga menggunakan data pelengkap lainnya dari literatur-literatur yang berkaitan, jurnal, buku, dan dari media internet.

\subsection{Metode Analisis}

Analisis data penelitian ini menggunakan metode VAR/VECM yang mana VAR merupakan model-model ekonometrika baik persamaan tunggal maupun persamaan ganda pada umumnya berbentuk persamaan struktural, yaitu model yang dibangun berdasarkan hubungan antar variabel yang mengacu pada penelitian terdahulu, VAR merupakan salah satu metode time series yang sering digunakan dalam penelitian, terutama dalam bidang ekonomi. Ketika peneliti tidak memiliki kepastian untuk menentukan bahwa suatu variabel adalah eksogen, maka VAR akan memperlakukan masing-masing variabel secara simetris (Gujarati, 2003). Analisis pada penilitian ini juga menggunakan analisis kausalitas Granger untuk melihat keberadaan hubungan sebab akibat antar variabel.

Metode pelaksanaan berisi metode-metode pelaksanaan yang sesuai teori dari buku ataupun artikel yang disitasi. Sitasi dilarang menggunakan akses dari sebuah website. Metode dituliskan secara rinci dan jelas. Jika perlu bisa digambarkan diagram alir untuk metode pelaksanaan sama dengan aturan untuk membuat diagram alir dari suatu algoritma.

\subsection{Model Penelitian}

Adapun bentuk model umum penelitian ini adalah sebagai berikut :

$$
\begin{aligned}
& \square \quad \square
\end{aligned}
$$

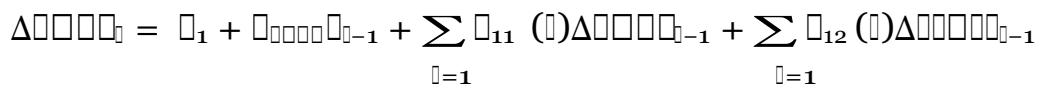

$$
\begin{aligned}
& +\sum_{l=1}^{\square} \square_{13}(\mathrm{a}) \Delta \square \square \square_{-1}+\sum_{\mathrm{l}=1}^{\square} \square_{14}(\mathrm{I}) \Delta \square \square \square_{1-1}+\sum_{\mathrm{l}=1}^{\square} \square_{15}(\mathrm{I}) \Delta \square \square \square_{l-1} \\
& +\sum_{\mathrm{l}=1}^{\square} \square_{16}(\mathrm{D}) \Delta \square \square \square_{\mathrm{l}-1}+\sum_{\mathrm{l}=1}^{\square} \square_{17}(\mathrm{D}) \Delta \square \square \square_{\mathrm{l}-1}+\sum_{\mathrm{l}=1}^{\square} \square_{18}(\mathrm{D}) \Delta \square \square \square_{\mathrm{l}-1} \\
& \text { 미 } \\
& +\sum_{l=1} \square_{19}(\square) \Delta \square \square \square \square_{1-1}+\square_{0 u}
\end{aligned}
$$




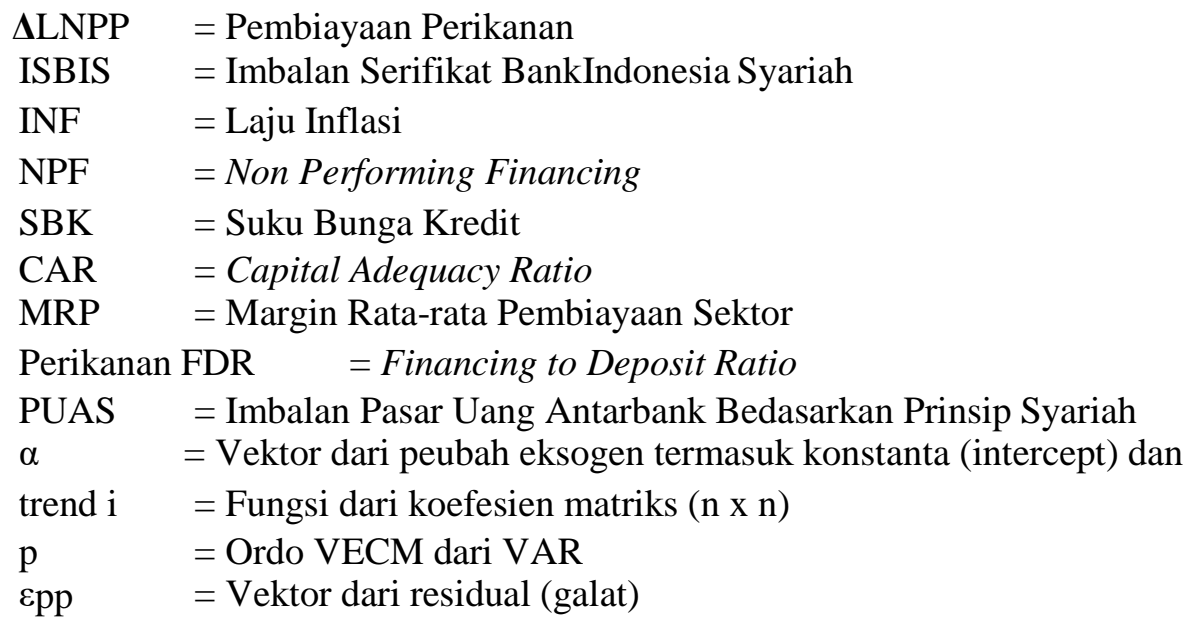

Sedangkan definisi dari variabel-variabel pada penelitian ini adalah sebagai berikut :

a. Pembiayaan Perikanan (LNPP), merupakan jumlah pembiayaan yang disalurkan perbankan syariah di indonesia pada sektor perikanan.

b. Inflasi (INF), merupakan tingkat laju inflasi selama kurun waktu Oktober 2014 sampai dengan sampai dengan Mei 2019.

c. Non Performance Financing (NPF) perikanan, yaitu tingkat pembiayaan bermasalah yang ada pada pembiayaan syariah untuk sektor perikanan.

d. Suku Bunga Kredit (SBK), merupakan suku bunga kredit modal kerja pada perbankan di Indonesia.

e. Capital Adequacy Ratio (CAR), rasio kecukupan modal yang berfungsi menampung risiko kerugian yang kemungkinan dihadapi oleh perbankan syariah di indonesia.

f. Financing to Deposit Ratio (FDR), rasio untuk mengukur komposisi jumlah pembiayaan yang diberikan dibandingkan dengan jumlah dana masyarakat dan modal sendiri yang digunakan.

g. Margin Rata-rata Pembiayaan perikanan (MRP), merupakan profit yang diambil oleh bank dari pembiayaan yang dibebankan oleh perbankan syariah di Indonesia kepada sektor perikanan.

h. PUAS, merupakan instrument keuangan berdasarkan prinsip syariah yang diterbitkan oleh perbankan syariah di Indonesia.

i. Imbalan SBIS (ISBIS), merupakan imbalan bagi hasil dari sertifikat Bank Indonesia pada periode Oktober 2014 sampai dengan sampai dengan Mei 2019.

\subsection{Uji Asumsi}

Berikut penjelasan uji-uji asumsi dalam analisis VAR/VECM, antara lain:

a. Uji Stasioneritas

Uji Stasioneritas merupakan langkah awal dalam mengestimasi model VAR, untuk memastikan bahwa data yang digunakan adalah stasioner. Stasioneritas juga merupakan salah satu konsep dasar dalam analisis data time series. Data time series terlebih dahulu harus stasioner sebab berkaitan dengan metode estimasi yang digunakan. Data time series yang bersifat stationer bisa diolah dengan VAR dengan metode standar, sedangkan data time series yang bersifat tidak stationer maka akan berimplikasi pada VAR dalam bentuk difference atau VECM. Uji stationer digunakan agar estimasi regresi yang dihasilkan tidak mengandung fenomena nonsense regression (spurios regression). Kejadian tersebut menggambarkan 
hubungan variabel yang nampaknya signifikan secara statistik namun sebenarnya tidak memiliki hubungan. Hal ini dapat dilihat dari nila R2 yang mendekati nol, serta nilai R2 yang lebih besar dari Durbin-Watson Statistik. Untuk menguji stationeritas data penelitian dengan metode ini menggunakan Dickey-Fuller (DF) test dan Augmented Dickey-Fuller (ADF) test, seseuai dengan bentuk trend deterministik yang dikandung oleh setiap variabel (Gujarati, 2003).

b. Lag Optimum

Setelah uji ADF sebagaimana yang telah dijelaskan di atas maka satu hal yang paling menentukan dalam uji stationaritas adalah penentuan lag. Penetapan lag optimal dapat ditentukan dengan cara menetapkan nilai lag yang dapat diperoleh dari LR (squential modified LR test statictic), FPE (Final Prediction Error), AIC (Akaike Information Criterian), SC (Schwarz Information Criterian), HQ (Hamman-Quinn Information Criterian).

c. Kointegrasi

Dalam analisis VAR/VECM, kointegrasi digunakan untuk mengetahui keberadaan hubungan jangka panjang antara variabel-variabel yang tidak stationer. Kointegrasi memiliki arti, walaupun secara individu tidak stationer, namun kombinasi linier dari dua atau lebih variabel- variabel tersebut dapat menjadi stationer (Tanjung dan Devi, 2013).

d. Impulse Response Function (IRF)

Analisis Impulse Response Function (IRF) bertujuan untuk mengetahui berapa lama waktu yang dibutuhkan bagi suatu varibel dalam memberikan respon atas perubahan yang terjadi pada variabel lainnya. IRF juga mampu melacak pengaruh kontemporer dari inovasi (shock) suatu variabel tertentu sebesar satu standar deviasi terhadap nilai-nilai variabel endogen dalam sistem pada saat ini dan nilai mendatang.

e. Variance Decomposition (VD)

Analisis Variance Decomposition (VD) atau dikenal sebagai forecast error variance decomposition digunakan untuk memprediksi kontribusi prosentase varians setiap variabel karena adanya perubahan variabel tertentu dalam sistem. Pengujian ini memberikan informasi mengenai proporsi dari pergerakan pengaruh shock pada satu variabel terhadap variabel variabel lainnya pada saat ini dan periode kedepannya.

\section{HASIL DAN PEMBAHASAN}

\subsection{Uji Stasionaritas}

Pengujian stasioneritas pada penelitian ini menggunakan uji Augmented Dickey Fuller (ADF), dengan nilai kritis sebesar 5 persen. Pengujian dilakukan pada tahap level sampai dengan first difference dengan menggunakan asumsi Schwarz Information Criterion pada automatic lag length selection dengan maximum lag sebesar 10.

\begin{tabular}{|c|cc|cc|}
\hline \multirow{2}{*}{ Variabel } & \multicolumn{2}{|c|}{ Level } & \multicolumn{2}{c|}{ First Difference } \\
\cline { 2 - 5 } & Nilai ADF & Nilai t-Statistik (5\%) & Nilai ADF & Nilai t-Statistik (5\%) \\
\hline LNPP & -2.023413 & -3.493692 & $\mathbf{- 6 . 9 5 8 6 1 0}$ & -3.496960 \\
INF & -2.245774 & -3.493692 & $\mathbf{- 5 . 5 9 1 1 2 4}$ & -3.496960 \\
NPF & $\mathbf{- 4 . 9 2 5 8 3 7}$ & -3.493692 & $\mathbf{- 9 . 0 9 4 3 1 6}$ & -3.496960 \\
SBK & -0.641945 & -3.493692 & $\mathbf{- 7 . 7 8 4 3 1 0}$ & -3.495295 \\
CAR & -2.458688 & -3.493692 & $\mathbf{- 7 . 3 0 9 7 4 2}$ & -3.495295 \\
FDR & -2.092308 & -3.493692 & $\mathbf{- 8 . 0 3 7 2 5 5}$ & -3.495295 \\
MRP & $\mathbf{- 4 . 5 4 1 1 1 3}$ & -3.493692 & $\mathbf{- 1 0 . 7 5 1 3 3}$ & -3.495295 \\
PUAS & $\mathbf{- 4 . 5 8 8 3 5 7}$ & -3.493692 & $\mathbf{- 1 1 . 3 1 7 6 9}$ & -3.495295 \\
ISBIS & -1.657272 & -3.495295 & $\mathbf{- 4 . 6 5 5 3 7 9}$ & -3.495295 \\
\hline
\end{tabular}

Tabel 1: Uji Stasionaritas 
Data dikatakan stasioner adalah ketika nilai statistik ADF kurang dari nilai kritis MacKinnon. Hasil yang dicetak tebal pada Tabel diatas menunjukkan data yang stasioner baik pada level maupun first difference. Hasil pengujian menunjukkan semua variabel tidak stasioner pada tingkat level kecuali variabel NPF, MRP dan PUAS. Sedangkan pada first difference semua variabel stasioner. Oleh karena itu, akan dilakukan pengujian kointegrasi, jika terdapat kointegrasi maka akan digunakan model Vector Error Correction Model (VECM), namun apabila tidak terdapat kointegrasi maka akan digunakan VAR first difference.

\subsection{Penentuan Lag Optimum}

Tahap pengujian lag optimum ini sangat berguna untuk menghilangkan autokorelasi dalam sistem VAR. Sehingga dengan digunakannya lag optimal dapat mencegah muncul kembali masalah autokorelasi. Penetapan lag optimal yang digunakan dalam penelitian ini berdasarkan lag terpendek dengan menggunakan Akaike Information Criterion (AIC). Berdasarkan model LNPP yang diteliti dengan menggunakan variabel INF, NPF, SBK, CAR, FDR, MRP, IPUAS, dan ISBIS mengalami titik optimum pada lag 4 sehingga dapat diolah lebih lanjut. kemudian, berdasarkan FPE lag optimum juga berada pada lag 4 sehingga kesimpulannya adalah model LNPP dapat diolah lebih lanjut.

\begin{tabular}{|ccccccc|}
\hline Lag & LogL & LR & FPE & AIC & SC & HQ \\
\hline 0 & -3140.161 & NA & $3.48 \mathrm{e}+42$ & 123.4965 & $123.8374^{*}$ & $123.6268^{*}$ \\
1 & -3074.180 & 106.0878 & $6.57 \mathrm{e}+42$ & 124.0855 & 127.4946 & 125.3882 \\
2 & -2993.878 & 100.7709 & $9.05 \mathrm{e}+42$ & 124.1129 & 130.5902 & 126.5880 \\
3 & -2866.955 & $114.4796^{*}$ & $3.62 \mathrm{e}+42$ & 122.3120 & 131.8574 & 125.9596 \\
4 & -2713.778 & 84.09730 & $2.05 \mathrm{e}+42^{*}$ & $119.4815^{*}$ & 132.0952 & 124.3015 \\
\hline
\end{tabular}

Tabel 2: Lag Optimum

\subsection{Uji Kointegrasi}

\begin{tabular}{|ccccc|}
\hline $\begin{array}{c}\text { Hypothesized } \\
\text { No. of CE(s) }\end{array}$ & Eigenvalue & $\begin{array}{c}\text { Trace } \\
\text { Statistic }\end{array}$ & $\begin{array}{c}0.05 \\
\text { Critical Value }\end{array}$ & Prob. $^{* *}$ \\
\hline None * & 0.899154 & 346.9750 & 197.3709 & 0.0000 \\
At most 1 * & 0.662987 & 225.3846 & 159.5297 & 0.0000 \\
At most 2 * & 0.605250 & 167.7401 & 125.6154 & 0.0000 \\
At most 3 * & 0.527581 & 118.4765 & 95.75366 & 0.0006 \\
At most 4 * & 0.441889 & 78.73236 & 69.81889 & 0.0082 \\
At most 5 & 0.354460 & 47.82288 & 47.85613 & 0.0504 \\
At most 6 & 0.231222 & 24.62646 & 29.79707 & 0.1752 \\
At most 7 & 0.121949 & 10.68992 & 15.49471 & 0.2313 \\
At most 8 & 0.069140 & 3.797265 & 3.841466 & 0.0513 \\
\hline
\end{tabular}

Tabel 3: Uji Kointegrasi

Fenomena data yang tidak stasioner pada tingkat level bisa menghasilkan hubungan keseimbangan jangka panjang yang biasa dikenal dengan sebutan kointegrasi. Dengan menggunakan uji kointegrasi Johansen (Johansen Cointegration Test), akan melihat ada tidaknya hubungan kointegrasi pada veriabel-variabel tersebut. Hasil dari pengujian ini akan menentukan metode analisis yang akan dipakai apakah VAR first difference atau VECM. Berdasarkan tabel di atas dapat dilihat bahwa nilai trace statistic dan maximum eigenvalue pada $\mathrm{r}=0$ lebih besar dari critical value dengan tingkat signifikansi 5\%. Hal ini berarti uji kontegrasi mengindikasikan 
bahwa di antara pergerakan INF, NPF, SBK, CAR, FDR, MRP, PUAS, ISBIS dan LNPP memiliki hubungan stabilitas/keseimbangan dan kesamaan pergerakan dalam jangka panjang. Atau dengan kata lain, setiap periode jangka pendek, seluruh variabel cenderung saling menyesuaikan untuk mencapai ekuilibrium jangka panjangnya.

\subsection{Uji Kausalitas Granger}

Pada uji kausalitas Granger, apabila nilai Probability lebih kecil dari tariff nyata yang digunakan, maka dapat disimpulkan adanya hubungan Granger di antara peubah yang ada, pada penilitian ini taraf nyata adalah sebesar 5 persen. Berdasarkan tabel dibawah ini, dapat diketahui adanya hubungan Granger satu arah antara pembiayaan perikanan (LNPP) dengan NPF, dan pembiayaan perikanan (LNPP) dengan SBK. Hal ini menunjukkan bahwa secara Granger, pembiayaan perikanan mempengaruhi NPF, dan pembiayaan perikanan mempengaruhi SBK. Namun demikian, tidak ditemukan hubungan Granger dengan arah sebaliknya.

\begin{tabular}{|lc|}
\hline Null Hypothesis: & Probability \\
\hline INF does not Granger Cause LNPP & 0.2328 \\
LNPP does not Granger Cause INF & 0.1082 \\
\hline NPF does not Granger Cause LNPP & 0.2027 \\
LNPP does not Granger Cause NPF & $\mathbf{0 . 0 1 6 4}$ \\
\hline SBK does not Granger Cause LNPP & 0.6756 \\
LNPP does not Granger Cause SBK & $\mathbf{0 . 0 0 4 9}$ \\
\hline \hline CAR does not Granger Cause LNPP & 0.5352 \\
LNPP does not Granger Cause CAR & 0.2895 \\
\hline FDR does not Granger Cause LNPP & 0.5665 \\
LNPP does not Granger Cause FDR & 0.2084 \\
\hline MRP does not Granger Cause LNPP & 0.3563 \\
LNPP does not Granger Cause MRP & 0.3510 \\
\hline PUAS does not Granger Cause LNPP & 0.3624 \\
LNPP does not Granger Cause PUAS & 0.8049 \\
\hline ISBIS does not Granger Cause LNPP & 0.8872 \\
LNPP does not Granger Cause ISBIS & 0.0652 \\
\hline
\end{tabular}

Tabel 4: Uji Kausalitas Granger

\subsection{Estimasi VECM}

Hasil estimasi VECM akan didapat hubungan jangka pendek dan jangka panjang antara INF, NPF, SBK, CAR, FDR, MRP, PUAS, SBIS dan LNPP. Pada estimasi ini, LNPP merupakan variabel dependen sedangkan variabel indpendennya adalah INF, NPF, SBK, CAR, FDR, MRP, PUAS, dan ISBIS. Hasil estimasi VECM untuk menganalisis pengaruh jangka pendek dan jangka panjang pengaruh variabel independen terhadap variabel dependen.

\begin{tabular}{|l|l|l|}
\hline Variabel & Koefisien & T statistik \\
\hline CointEq1 & -0.267564 & -3.56306 \\
\hline $\mathrm{D}($ LNPP(-1)) & -0.082349 & -0.51916 \\
\hline $\mathrm{D}(\mathrm{LNPP}(-2))$ & 0.070217 & 0.46256 \\
\hline
\end{tabular}




\begin{tabular}{|l|l|l|}
\hline$D(I N F(-1))$ & $-9.55 \mathrm{E}+09$ & -0.38470 \\
\hline$D(I N F(-2))$ & $-8.65 \mathrm{E}+10$ & -2.56563 \\
\hline$D(N P F(-1))$ & -4.474641 & $-\mathbf{3 . 6 1 2 1 8}$ \\
\hline$D(N P F(-2))$ & -1.494135 & -1.51572 \\
\hline$D(S B K(-1))$ & $-2.15 \mathrm{E}+11$ & -1.23828 \\
\hline$D(S B K(-2))$ & $-3.10 \mathrm{E}+11$ & -1.69644 \\
\hline
\end{tabular}

Tabel 5: Faktor-Faktor yang Mempengaruhi Perubahan LNPP Pada Jangka Pendek

Berdasarkan hasil yang disajikan pada tabel di atas, pada jangka pendek terdapat dua variabel pada taraf nyata 5\% yang berpengaruh signifikan terhadap perubahan LNPP untuk jangka pendek, yaitu variabel NPF, dan variabel PUAS pada lag 1. NPF berpengaruh negatif signifikan terhadap LNPP. Artinya, kenaikan pada NPF 1\% akan berdampak pada penurunan LNPP di Indonesia sebesar $-3.61218 \%$ untuk jangka pendek. PUAS berpengaruh negatif signifikan terhadap LNPP. Artinya, kenaikan pada PUAS 1\% akan berdampak pada penurunan LNPP di Indonesia sebesar $-3.73681 \%$ untuk jangka pendek.

NPF diketahui memiliki dampak signifikan dan negatif terhadap pembiayaan perikanan dalam jangka pendek. Hal ini terjadi karena tingkat jumlah pembiayaan bermasalah pada sektor perikanan mengakibatkan bank syariah enggan dan cenderung mengurangi jumlah pembiayaan ketika terjadi kemacetan dalam pembiayaan yang disalurkannya. Hal ini menjadi kebijakan yang sering diambil oleh bank syariah ketika terjadi masalah pada semua jenis pembiayaannya tidak hanya pada sektor perikanan, secara umum juga dibuktikan oleh Prastanto (2013), dan Adzimatinur, Hartoyo, dan Wiliasih (2015). Dalam jangka panjang dapat kita lihat pada tabel dibawah bahwa juga NPF berpengaruh negatif signifikan terhadap LNPP. Artinya, kenaikan pada NPF 1\% akan berdampak pada penurunan LNPP di Indonesia sebesar $-14.50838 \%$ untuk jangka panjang.

Kemudian variabel lain yang memiliki dampak adalah variabel PUAS secara signifikan dan negatif terhadap pembiayaan perikanan dalam jangka panjang. Perbankan syariah sebagai lembaga intermediasi memiliki peran menyalurkan dana yang terhimpun, penyaluraan pembiayaan tersebut dapat ditempatkan pada Pasar Uang Antarbank Syariah (PUAS), akan tetapi jika perbankan syariah menempatkan dananya pada PUAS dengan proporsi yang tinggi maka hal itu dapat menekan penyaluran pembiayaan pada sektor riil dalam kasus ini adalah sektor perikanan, karena ketika terjadi peningkatan penempatan dana perbankan pada PUAS maka akan diikuti dengan penurunan porsi penyaluran dana untuk pembiayaan sektor riil (Jaya, Rindayati, dan Ali 2015). Adapun untuk jangka panjang pada tabel dibawah dapat kita ketahui bahwa PUAS berpengaruh negatif signifikan terhadap LNPP. Artinya, kenaikan pada PUAS $1 \%$ akan berdampak pada penurunan LNPP di Indonesia sebesar -9.32E+08\% untuk jangka panjang.

\begin{tabular}{|l|l|l|}
\hline Variabel & Koefisien & T statistic \\
\hline INF(-1) & $-1.53 \mathrm{E}+11$ & $\mathbf{- 4 . 8 7 5 1 6}$ \\
\hline $\mathrm{NPF}(-1)$ & -14.50838 & $\mathbf{- 9 . 1 4 8 8 6}$ \\
\hline SBK(-1) & $-2.59 \mathrm{E}+11$ & -2.73962 \\
\hline CAR(-1) & $5.27 \mathrm{E}+11$ & $\mathbf{1 4 . 2 3 7 1}$ \\
\hline FDR(-1) & $2.23 \mathrm{E}+11$ & $\mathbf{1 2 . 8 1 0 6}$ \\
\hline MRP(-1) & $9.24 \mathrm{E}+09$ & 0.81121 \\
\hline PUAS(-1) & $-9.32 \mathrm{E}+08$ & $\mathbf{- 8 . 6 3 6 8 0}$ \\
\hline ISBIS(-1) & $-7.85 \mathrm{E}+11$ & $\mathbf{- 1 1 . 5 6 9 8}$ \\
\hline
\end{tabular}

Tabel 6: Faktor-Faktor yang Mempengaruhi Perubahan LNPP Pada Jangka Panjang 
Berdasarkan hasil yang disajikan pada tabel Model Estimasi VECM kemudian diresume pada tabel di atas, pada jangka panjang terdapat delapan variabel pada taraf nyata $5 \%$ yang berpengaruh signifikan terhadap perubahan LNPP untuk jangka panjang, yaitu variabel INF, NPF, SBK, CAR, FDR, MRP, PUAS dan ISBIS.

INF berpengaruh negatif signifikan terhadap LNPP. Artinya, kenaikan pada INF $1 \%$ akan berdampak pada penurunan LNPP di Indonesia sebesar $-1.53 \mathrm{E}+11 \%$ untuk jangka panjang. Inflasi memiliki dampak negatif pada rasio pembiayaan perikanan, hubungan negatif ini dikarenakan apabila inflasi meningkat maka dengan hal itu otoritas moneter akan merespon dengan menerapkan kebijakan uang ketat (tight money policy), dengan respon tersebut Bank Indonesia akan membatasi jumlah uang yang beredar dengan cara diantaranya membatasi penyaluran kredit dan pembiayaan (Jaya, Rindayati, dan Ali 2015).

ISBIS berpengaruh negatif signifikan terhadap LNPP. Artinya, kenaikan pada ISBIS $1 \%$ akan berdampak pada penurunan LNPP di Indonesia sebesar $-7.85 \mathrm{E}+11 \%$ untuk jangka panjang. Bank Indonesia melakukan operasi pasar untuk mengendalikan jumlah uang beredar, adapun alat yang dipakai Bank Indonesia yang berdasarkan prinsip syariah adalah Sertifikat Bank Indonesia Syariah (SBIS). Pada saat imbalan SBIS naik maka bank syariah lebih memilih menempatkan dananya pada SBIS dibandingkan menyalurkan dananya pada pembiayaan sektor riil dan sebaliknya apabila imbalan SBIS turun maka bank lebih memilih menyalurkan dananya kepada masyarakat melalui pembiayaan karena dinilai lebih menguntungkan. Dengan demikian dapat diartikan bahwa SBIS memiliki pengaruh negatife terhadap pembiayaan perbankan syariah, dimana ketika imbalan SBIS semakin naik maka hal itu akan mengurangi jumlah penyaluran pembiyaan bank syariah di sektor riil (Wardiantika, Kusumaningtias 2014).

CAR mencerminkan rasio kecukupan modal suatu bank, apabila rasio CAR tinggi maka hal itu menandakan dana masyarakat yang terhimpun oleh bank semakin banyak, tentunya hal ini berdampak dalam melaksanakan fungsi intermediasi bank secara baik. Pada penelitian ini CAR berpengaruh positif signifikan terhadap LNPP. Artinya, kenaikan pada CAR 1\% akan berdampak pada kenaikan LNPP di Indonesia sebesar 5.27E+11\% untuk jangka panjang. Kemudian FDR berpengaruh positif signifikan terhadap LNPP. Artinya, kenaikan pada FDR 1\% akan berdampak pada kenaikan LNPP di Indonesia sebesar 2.23E+11\% untuk jangka panjang. Untuk mengetahui kemampuan bank dalam menjalankan fungsi intermediasi, kita dapat melihat indikator Financing to Deposit Ratio (FDR), apabila rasio FDR pada suatu bank tinggi maka dapat dikatakan bank tersebut mampu menjalankan fungsi intermediasinya secara baik. Dalam hal ini rasio FDR berdampak signifikan dan positif pada pembiayaan, semakin besar rasio FDR maka semakin besar pula jumlah pembiayaan ( Umiyati dan Ana 2017)

Adapun variabel SBK dan MRP tidak berpengaruh signifikan terhadap LNPP untuk jangka panjang. Hal ini menandakan bahwa bank syariah mampu beroperasi dengan konsep syariahnya dan tidak dipengaruhi suku bunga, sehingga pada pembiayaan perikanan di bank syariah untuk jangka panjang tidak terpengaruhi oleh Suku Bunga Kredit. Kemudian pembiayaan perikanan tidak juga dipengaruhi oleh tingkat margin rata-rata pembiayaan, hal ini memiliki arti akad yang diterapkan oleh bank syariah sudah tepat dan jumlah margin yang ditawarkan oleh bank syariah dirasa adil oleh nasabah. 
Nur Laili et al. Analysis of Factors

\subsection{Analisis Impulse Respon Function (IRF)}

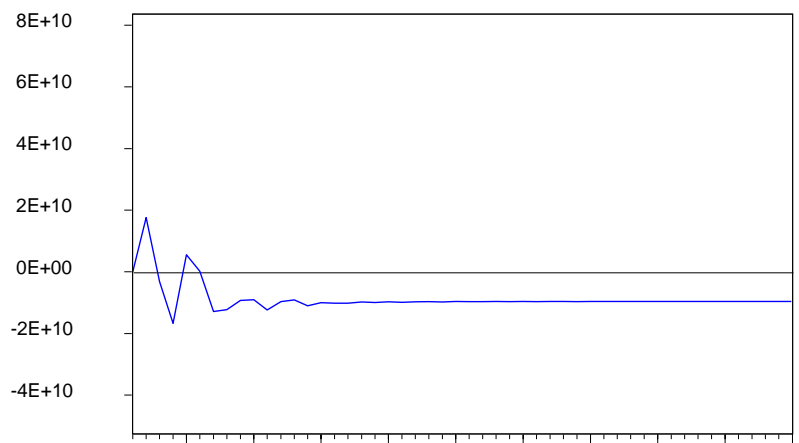

Gambar 3: Respon Pembiayaan Perikanan terhadap Inflasi (NPF)

Pada gambar IV.1, dapat diketahui saat terjadi guncangan pada inflasi, Pembiayaan Perikanan merespon positif mulai dari bulan ke-2, kemudian merespon negatif pada bulan ke-4, kembali merespon positif pada bulan ke-5 dan merespon negatif pada bulan berikutnya hingga mencapai titik minimum pada bulan ke-7. Respon Pembiayaan Perikanan terhadap guncangan yang diterima inflasi mulai stabil pada bulan ke-18.

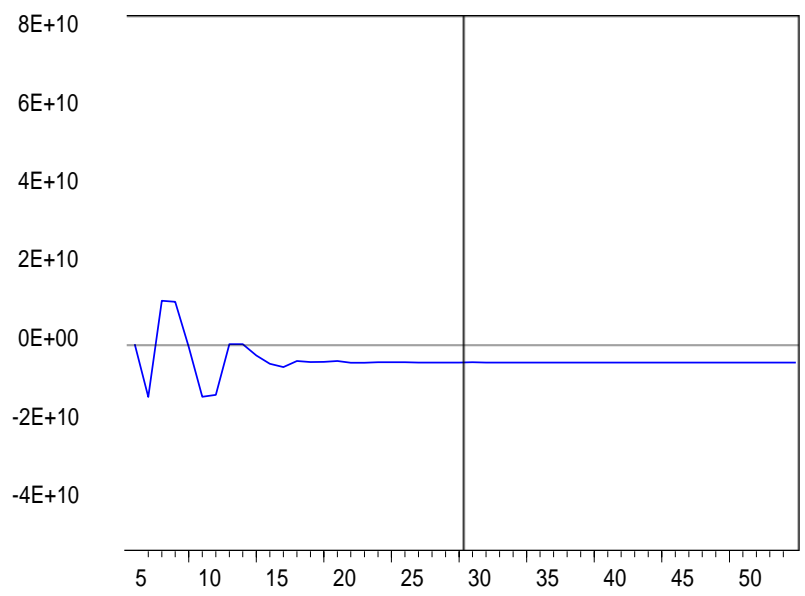

Pada gambar IV.2, dapat dilihat pada bulan ke-2 Pembiayaan Perikanan merespon negatif terhadap guncangan yang terjadi pada NPF, pada bulan ke-3 Pembiayaan Perikanan merespon positif tetapi bulan berikutnya kembali merespon negatif sampai pada puncak minimum di bulan ke-6. Respon Pembiayaan Perikanan terhadap guncangan yang diterima NPF mulai stabil pada bulan ke-13.

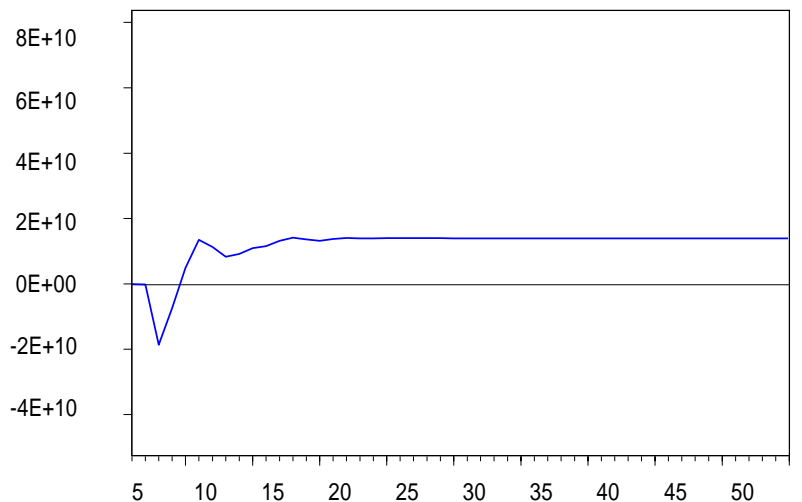

Gambar 5: Respon Pembiayaan Perikanan Terhadap Suku Bunga Kredit (SBK) 
Pada gambar IV.3, saat terjadi guncangan pada SBK, Pembiayaan Perikanan merespon negatif pada bulan ke-3, kemudian mulai merespon positif pada bulan ke-6 hingga mencapai titik maksimum pada bulan ke-13. Respon Pembiayaan Perikanan terhadap guncangan yang diterima inflasi mulai stabil pada bulan ke-16.

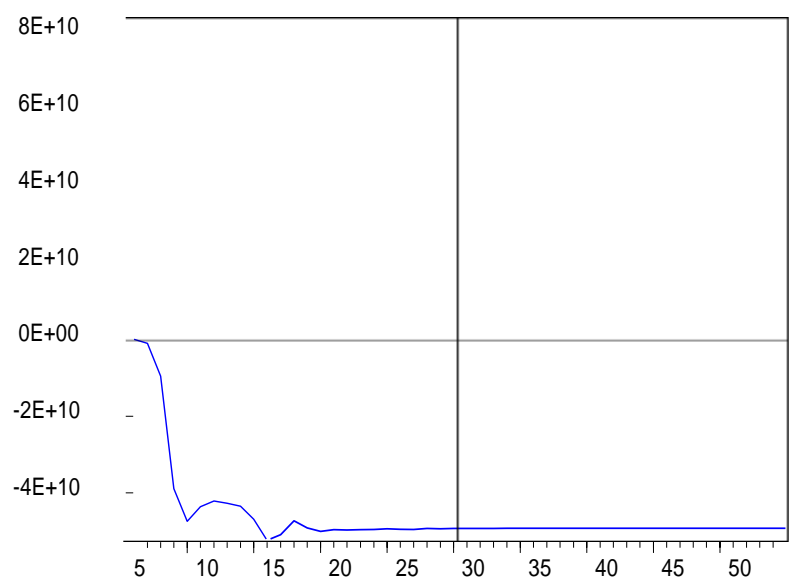

Gambar 6: Respon Pembiayaan Perikanan Terhadap Capital Adequacy Ratio (CAR)

Pada gambar IV.4, saat terjadi guncangan pada CAR, Pembiayaan Perikanan mulai merespon negatif pada bulan ke-2, dan mencapai titik minimum pada bulan ke-11. Respon Pembiayaan Perikanan terhadap guncangan yang diterima CAR mulai stabil pada bulan ke-16.

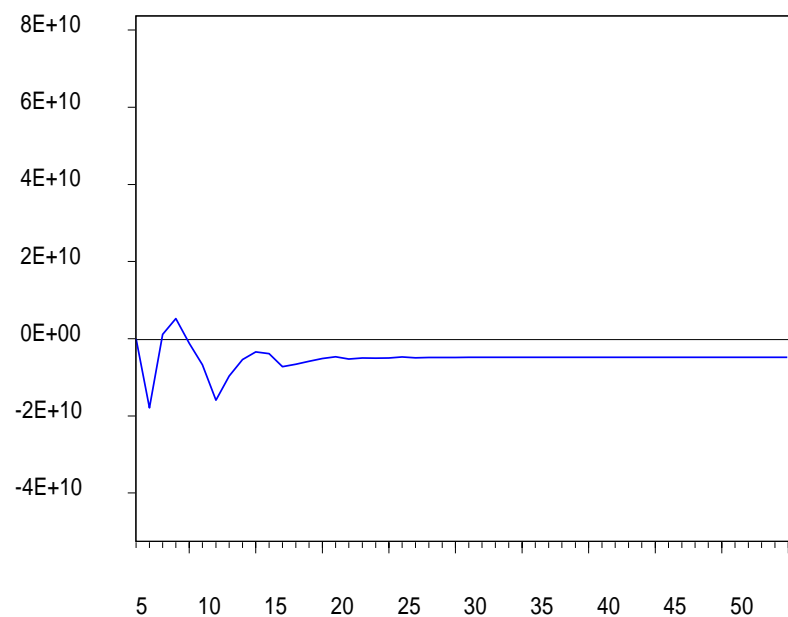

Gambar 7: Respon Pembiayaan Perikanan Terhadap Financing to Deposit Ratio (FDR)

Pada gambar IV.5, saat terjadi guncangan pada FDR, Pembiayaan Perikanan mulai merespon negatif pada bulan ke-2, kemudian merespon positif pada bulan ke-3 dam kembali merespon negatif pada bulan berikutnya hingga mencapai titik minimum pada bulan ke-7. Respon Pembiayaan Perikanan terhadap guncangan yang diterima FDR mulai stabil pada bulan ke- 21 . 


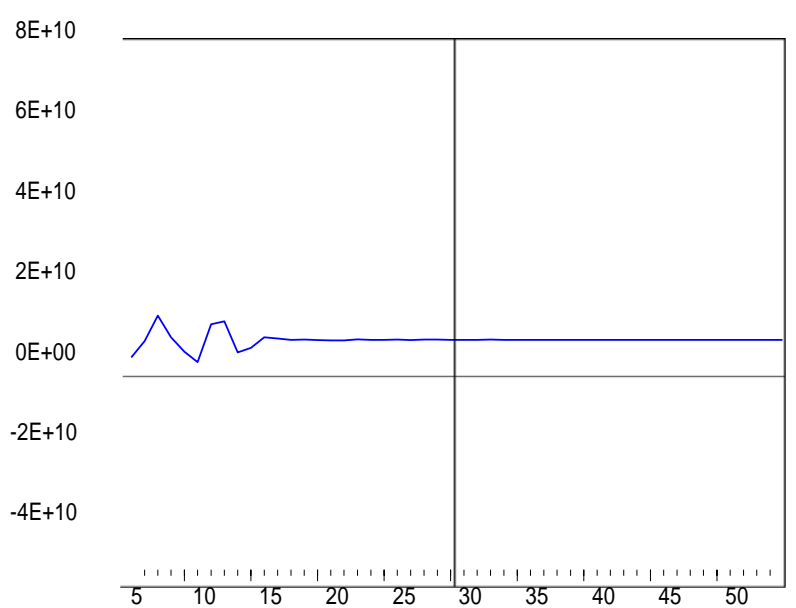

Gambar 8: Respon Pembiayaan Perikanan Terhadap Margin Rata-rata Pembiayaan (MRP)

Pada gambar IV.6, saat terjadi guncangan pada MRP, Pembiayaan Perikanan mulai merespon positif pada bulan ke-1, dan mencapai titik maksimum pada bulan ke-8. Respon Pembiayaan Perikanan terhadap guncangan yang diterima MRP mulai stabil pada bulan ke-12.

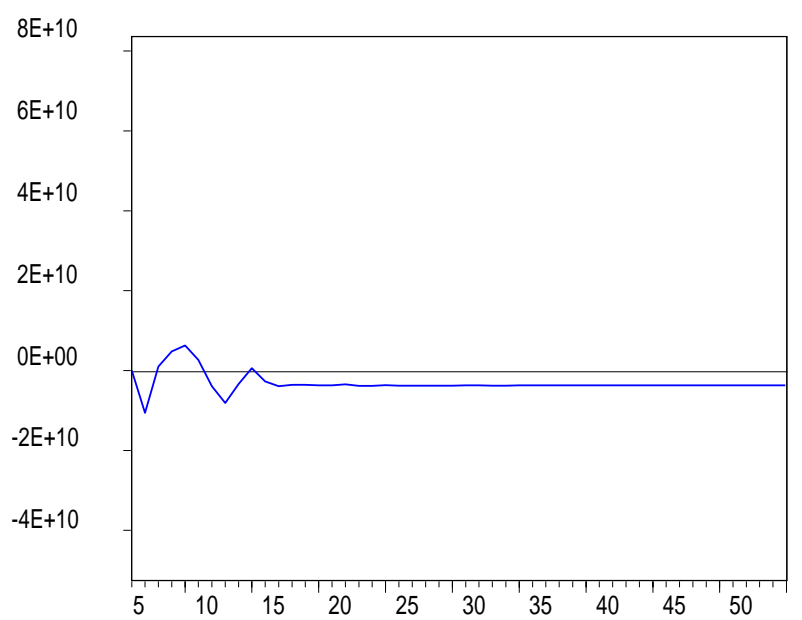

Gambar 9: Respon Pembiayaan Perikanan Terhadap Pasar Uang Antarbank Berdasarkan Prinsip Syariah (PUAS)

Pada gambar IV.7, saat terjadi guncangan pada PUAS, Pembiayaan Perikanan mulai merespon negatif pada bulan ke-1, kemudian merespon positif pada bulan ke-3 dan bulan berikutnya kembali merespon negatif hingga mencapai titik minimum pada bulan ke-8. Respon Pembiayaan Perikanan terhadap guncangan yang diterima PUAS mulai stabil pada bulan ke- 13 .

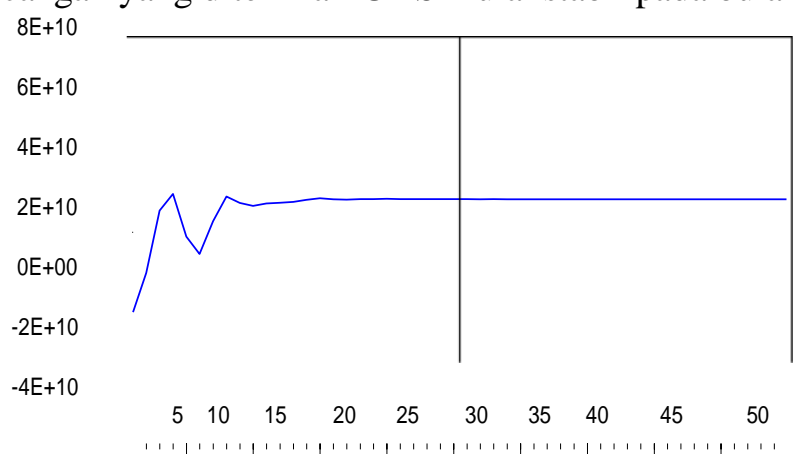

Gambar 10: Respon Pembiayaan Perikanan Terhadap Imbalan Sertifikat Bank Indonesia Syariah 
Pada gambar IV.8, saat terjadi guncangan pada ISBIS, Pembiayaan Perikanan mulai merespon positif pada bulan ke-1, dan mencapai titik maksimum pada bulan ke-4. Respon Pembiayaan Perikanan terhadap guncangan yang diterima ISBIS mulai stabil pada bulan ke- 14 .

\subsection{Analisis Variance Decomposition (VD)}

\begin{tabular}{|cccccccccc|}
\hline \hline Period & LNPP & INF & NPF & SBK & CAR & FDR & MRP & PUAS & ISBIS \\
\hline 1 & 100.0000 & 0.000000 & 0.000000 & 0.000000 & 0.000000 & 0.000000 & 0.000000 & 0.000000 & 0.000000 \\
2 & 90.32452 & 2.881155 & 1.690315 & 0.000260 & 0.010186 & 2.996509 & 0.149409 & 1.048956 & 0.898688 \\
5 & 74.58875 & 2.000292 & 1.337845 & 1.350897 & 12.25977 & 1.118899 & 0.480399 & 0.561608 & 6.301545 \\
10 & 69.80249 & 1.480942 & 1.032001 & 1.343349 & 17.85061 & 1.045219 & 0.409658 & 0.368463 & 6.667262 \\
15 & 67.50220 & 1.323389 & 0.710686 & 1.491545 & 20.56941 & 0.760512 & 0.326582 & 0.269777 & 7.045901 \\
20 & 66.72867 & 1.219368 & 0.564073 & 1.606338 & 21.50274 & 0.610505 & 0.284528 & 0.229978 & 7.253804 \\
25 & 66.32798 & 1.152835 & 0.484773 & 1.673610 & 21.99007 & 0.524816 & 0.262228 & 0.209088 & 7.374600 \\
30 & 66.08910 & 1.108253 & 0.434765 & 1.715330 & 22.28680 & 0.470273 & 0.248259 & 0.195728 & 7.451494 \\
35 & 65.92630 & 1.077256 & 0.400242 & 1.743474 & 22.49033 & 0.432681 & 0.238684 & 0.186500 & 7.504530 \\
40 & 65.80769 & 1.054544 & 0.374972 & 1.763945 & 22.63898 & 0.405214 & 0.231673 & 0.179723 & 7.543257 \\
50 & 65.64551 & 1.023557 & 0.340450 & 1.791849 & 22.84223 & 0.367719 & 0.222095 & 0.170462 & 7.596125 \\
\hline \hline
\end{tabular}

Tabel 7: Analisis Variance Decomposition

Tabel Variance Decomposition menjelaskan variabel-variabel yang memberikan proporsi pada fluktuasi Pembiayaan Perikanan. Pada bulan pertama, keragaman fluktuasi Pembiayaan Perikanan didominasi oleh Pembiayaan Perikanan itu sendiri sebesar 100 persen, dan terus berlanjut hingga periode akhir dengan proporsi yang semakin menurun.

Keragaman mulai terlihat pada bulan kedua, dimana Pembiayaan Perikanan memberikan keragaman sebesar 90.32452 persen terhadap fluktuasinya sendiri. Pada periode tersebut variabel INF memberikan proporsi sebesar 2.881155 persen, NPF memberikan proporsi sebesar 1.690315 persen, SBK sebesar 0.000260 persen, CAR sebesar 0.010186 persen, FDR sebesar 2.996509 persen, MRP sebesar 0.149409 persen, PUAS sebesar 1.048956 persen, dan SBIS sebesar 0.898688 persen.

Pada bulan kedua dapat dilihat variabel yang memberikan keragaman paling besar terhadap Pembiayaan Perikanan adalah Variabel FDR dan diikuti oleh INF. Namun dari Bulan ke Bulan justru SBIS terus memberikan kontribusi yang besar kepada Pembiayaan Perikanan, sehingga pada akhir periode SBIS yang memberikan kontribusi lebih banyak, kemudian diikuti oleh CAR diurutan kedua. Adapun FDR dan INF kontribusinya menurun hingga akhir periode peramalan, yaitu bulan ke-50.

Untuk variabel lainnya seperti NPF, dan SBK, ternyata NPF memberikan kontribusi lebih besar pada Pembiayaan Perikanan dibandingkan dengan SBK. Kontribusi NPF terus menurun hingga akhir periode peramalan, yaitu bulan ke-50, sedangkan SBK kontribusinya terus meningkat hingga akhir periode peramalan. Untuk variabel MRP, dan PUAS, ternyata MRP memberikan kontribusi lebih besar pada pembiayaan Perikanan dibandingkan PUAS hingga akhir periode peramalan.

\section{KESIMPULAN}

Beradasarkan penelitian yang telah dilakukan maka diperoleh kesimpulan sebagai berikut:

Pada jangka pendek Variabel NPF dan PUAS secara signifikan berpengaruh negatif, sedangkan pada jangka panjang secara signifikan variabel INF, NPF, PUAS, dan ISBIS memberikan pengaruh negatif terhadap Pembiayaan Perikanan. Adapun variabel CAR, dan FDR memberikan pengaruh 
positif terhadap Pembiayaan Perikanan, sedangkan variabel yang tidak berpengaruh signifikan untuk jangka panjang adalah variabel SBK dan MRP.

Pada analisis Impulse Respon Function dapat dibuktikan bahwa pembiayaan perikanan paling cepat mencapai kestabilan ketika berhadapan dengan guncangan pada Margin Rata-rata Pembiayaan (MRP), dibandingkan dengan guncangan pada variabel lainnya. Adapun variabel yang membentuk keragaman pada pembiayaan perikanan dengan kontribusi terbesar dijelaskan oleh CAR, lalu diikuti oleh ISBIS, SBK, INF, FDR, NPF, MRP, dan PUAS.

\section{UCAPAN TERIMAKASIH}

Artikel ini adalah hasil dari Program Pengabdian kepada Masyakarat yang dibiayai oleh BPPTN Universitas Sumatera Utara, sesuai dengan Surat Perjanjian Penugasan Pelaksanaan Pengabdian kepada Masyarakat Program Mono Tahun Dosen Muda, nomor: 331/UN5.2.3.2.1/PPM/2019, tanggal 20 Mei 2019. Tim Pengabdian mengucapkan terima kasih kepada Rektor dan LPPM USU atas dukungan dana dan fasilitas yang diberikan.

\section{DAFTAR PUSTAKA}

Adzimatinur, Fauziyah., Hartoyo, Sri., dan Wiliasih, Ranti. (2015). Faktor-Faktor yang Mempengaruhi Besaran Pembiayaan Perbankan Syariah di Indonesia, Jurnal Al Muzaraah, Bogor : Institut Pertanian Bogor

Badan Pusat Statistik. Oktober 2014 - Mei 2019, diunduh 12 Agustus 2019, dapat diakses www.bps.go.id

Bank Indonesia, Oktober 2014 - Meri 2019, diunduh 12 Agustus 2019, dapat diakses www.bi.go.id https://kkp.go.id/artikel/2896-bps-nilai-sub-sektor-perikanan-budidaya-mampu-dongkrak-

pertumbuhan-ekonomi, jam 10:09 AM. 6/25/2019

Ikatan Bankir Indonesia. (2014). Mengelola Bisnis Pembiayaan Bank Syariah. Jakarta: Gramedia Pustaka Utama.

Gujarati, Damodar N., 2003, Basic Econometrics Fourth Edition, New York: Gary Burke.

Laporan Kinerja KKP 2016, www.kkp.go.id

Lifstin Wardiantika dan Rohmawati Kusumaningtias. (2014). Pengaruh DPK, CAR, NPF, dan SWBI terhadap Pembiayaan Murabahah pada Bank Umum Syariah Tahun 2008-2012. Jurnal Ilmu Manajemen, Volume 2. Surabaya : Univesitas Negeri Surabaya.

Linda Nostbakken and Lars-Christian Sorensen. (2011). Invesment Behavior and Capacity Adjusment ini Fisheries : A Survey of the Literature, Marine Resource Economics, Volume 26, Denmark : University Copenhagen

Muhammad. (2018). Manajemen Bank Syariah, Yogyakarta : UPP STIM YKPN. Mulyadi, 2007, Ekonomi Kelautan, Jakarta, PT RajaGrafindo Persada.

Prastanto. (2013). Faktor yang Mempengaruhi Pembiayaan Murabahah pada Bank Umum Syariah di Indonesia. Accounting Analysis Journal, Volume 2, Semarang : Universitas Negeri Semarang.

Rouli anita velentina. (2018). Kebijakan Pembiyaan Bagi Nelayan Tradisional, Masalah-Masalah Hukum, jilid 47 No.3 Depok : Universitas Indonesia

Statistik Pembiayaan Syariah, OJK. Oktober 2014 - Mei 2019, diunduh 14 Agustus 2019, dapat diakses www.ojk.go.id

Statistik Sistem Keuangan Indonesia, Oktober 2014 - Mei 2019, diunduh 14 Agustus 2019, dapat diakses www.bi.go.id

Tanjung, Hendri dan Devi, Abrista. (2013). Metodologi Penelitian Ekonomi Islam. Jakarta: Granata Publishing.

Undang-Undang No.45 Tahun 2009 UU Perikanan

Undang-Undang No.31 Tahun 2004 tentang Perikanan 
Yozar Putra Jaya, Wiwiek Rindayati, dan Khalifah Muhammad Ali, 2015, Analisis Faktor-Faktor Penentu Pembiayaan Perbankan Syariah pada Sektor Pengangkutan dan Komunikasi di Indonesia, Jurnal Al Muzaraah, Volume 3, Bogor : Institut Pertanian Bogor 